\section{CMA President response: physician-assisted death}

Although Downar and colleagues ${ }^{1}$ present a very detailed examination of many of the issues involved in our growing national examination of how Canadians expect to manage their care at the end-oflife, the authors unfortunately get the cart well before the horse by focusing solely on physician-assisted death. Addressing the dire need for improved access to palliative care services, for which the late Dr. S. Lawrence Librach was an eloquent champion, and Canada's lack of a national pain strategy would be much better places to start.

Contrary to the authors' assertion, delegates attending the Canadian Medical Association (CMA) annual meeting last August were clear that physicians needed to know more about how Canadian society viewed the full spectrum of end-of-life care before they could rush to any change in the CMA's current policy position on physicianassisted death.

This has led the CMA to conduct a national dialogue on end-of-life care, gathering input from Canadians online and at public town hall meetings in St. John's, Newfoundland and Labrador; Vancouver, British Columbia; Whitehorse, Yukon Territory and Regina, Saskatchewan. Meetings wrap up in Mississauga, Ontario on May 27, 2014. The CMA is also conducting extensive discussions of these issues with members online and at town hallstyle meetings. Although physicians may need to be prepared for the challenges of physician-assisted death, we are hearing from Canadians that there is an even greater societal need for us to ensure we can provide high-quality palliative care to everyone who would need it and provide the public with a better understanding of advance care directives.

\section{Louis Hugo Francescutti MD PhD}

President, Canadian Medical Association, Ottawa, Ont.

\section{Reference}

1. Downar J, Bailey TM, Kagan J, et al. Physicianassisted death: time to move beyond Yes or No. CMAJ 2014;186:567-8.

\section{CMAJ 2014. DOI:10.1503/cmaj.114-0029}

\section{Of carts and horses ... [the authors respond]}

We agree with Francescutti's ${ }^{1}$ goal of improving access to palliative care, but there is no reason to think that this is a prerequisite for discussing physicianassisted death. Legalization of physicianassisted death need not hinder efforts to develop palliative care, and our article ${ }^{2}$ made this clear. Palliative care and advance-care planning improved considerably in Oregon after legalization, and Oregon is now a leader in the United States in a variety of palliative metrics. ${ }^{3}$ But even the best palliative care may not be sufficient for some patients, since $90 \%$ of Oregonians who received assisted death were enrolled in a hospice program. ${ }^{4}$ We have not put the cart before the horse. Francescutti should not overlook the main point of the article: the yes/no debate about assisted death could become practically obsolete in the very near future. While physicians are arguing about the relative positions of the cart and the horse, many Canadians have completed the journey on foot. Physicians do not need to lead or even agree with efforts to change Canadian law, but they have a professional responsibility to develop a Plan B at the very least. We need to begin the process of developing policies, protocols and guidelines, because we may need them in the near future.

We applaud the decision of the Canadian Medical Association (CMA) Board of Directors to hold national town hall meetings about end-of-life care, and to include as part of that a discussion of physician-assisted death. Dr. Francescutti himself has eloquently outlined the benefits of discussing physician-assisted death in this open manner. ${ }^{5}$ We hope that the feedback received at these town hall meetings will convince the CMA to take the lead on developing a Plan B, even if it continues to oppose a change in the law.
James Downar MDCM MHSc

(Bioethics), Tracey M. Bailey BA LLB, Jennifer Kagan MD

Divisions of Critical Care and Palliative Care (Downar), Department of Medicine, University of Toronto, Toronto, Ont.; John Dossetor Health Ethics Centre and Department of Psychiatry (Bailey), Faculty of Medicine and Dentistry, University of Alberta, Edmonton, Alta.; Division of Palliative Care (Kagan), Department of Family and Community Medicine,

University of Toronto, Toronto, Ont.

\section{References}

1. Francescutti LH. CMA President response: physician-assisted death. CMAJ 2014;186:614.

2. Downar J, Bailey TM, Kagan J, et al. Physicianassisted death: time to move beyond Yes or No. CMAJ 2014;186:567-8.

3. Quill TE. Legal regulation of physician-assisted death - the latest report cards. N Engl J Med 2007; 356:1911-3.

4. Loggers ET, Starks H, Shannon-Dudley M, et al. Implementing a Death with Dignity program at a comprehensive cancer center. N Engl J Med 2013; 368:1417-24

5. Kirkey S. "Parliament of medicine" could revisit stance on euthanasia as Canadians struggle with endof-life decisions. National Post [Toronto] 2013 Aug. 17. Available: http://news.nationalpost.com/2013 /08/17/parliament-of-medicine-could-revisit-stance -on-euthanasia-as-more-canadians-struggle-with-end -of-life-decisions/ (accessed 2014 Apr. 10).

\section{CMAJ 2014. DOI:10.1503/cmaj.114-0030}

\section{Health care and refugees in Canada}

I would like to address some of the inaccurate and misleading assertions Stanbrook made in his editorial in CMAJ.'

Stanbrook states "that the cuts to health coverage have, in particular, denied refugees access to primary and preventive care." That is absolutely false. Through the Interim Federal Health Program (IFHP), all genuine refugees in Canada receive primary health care coverage that is similar to that received under provincial or territorial health care programs.

Underlying the decision to reform the IFHP was the principle that those seeking asylum are not entitled to more generous benefits than those that Canadian taxpayers and legal immigrants receive. 
Canada is second to none in its generosity and fairness toward newcomers, as shown by our world-leading refugee resettlement system. But, Canada has no tolerance for those who take advantage of its generosity.

Recent changes to the IFHP should ensure that those who were rejected asylum no longer receive tax-payerfunded benefits that are more generous than those provided to Canadians.

With the recent reforms to the IFHP and the new asylum system in Canada, genuine refugees are getting the protection they need sooner. Failed asylum claimants with unfounded claims are being removed from Canada more quickly, and the generosity of Canadian taxpayers is no longer being abused.

\section{Chris Alexander MA}

Minister of Citizenship and Immigration, Government of Canada, Ottawa, Ont.

\section{Reference}

1. Stanbrook MB. Canada owes refugees adequate health coverage. CMAJ 2014;186:91.

CMAJ 2014. DOI:10.1503/cmaj.114-0031

\section{Response to Alexander}

Alexander's letter ${ }^{1}$ in response to Stanbrook's editorial ${ }^{2}$ is filled with inaccuracies.

Alexander states that "all genuine refugees in Canada receive primary health care coverage." Not true. Alexander must know that refugee claimants are not initially deemed as failed claimants or successful claimants in need of protection until they have had their refugee hearing. Until then, many are not receiving access to primary and preventive care, and some have no insurance in their first few weeks in Canada, which places communities at risk of preventable infectious diseases.

Alexander states "that those seeking asylum are not entitled to more generous benefits than those that Canadian taxpayers and legal immigrants receive." The minister must know that refugee claimants are lawfully within our borders, follow the rules and so are perfectly "legal." Alexander should know from the website of his own department that, under the previous system, claimants were receiving coverage that was identical to what low-income Canadians received through social assistance programs.
Alexander has publicly suggested that doctors are misleading Canadians. The Canadian Medical Association and other national health profession bodies have expressed concerns about these cuts. Alexander's office has failed to respond to a request for a meeting from the leadership of these organizations and he continues to ignore a request from Canadian Doctors for Refugee Care to publicly debate these issues.

Alexander, a former Canadian diplomat in Afghanistan, can do better than respond with a misinformation campaign to the suffering of people fleeing persecution.

Meb Rashid MD, Philip B. Berger MD

Cofounders (Rashid, Berger), Canadian Doctors for Refugee Care; Medical Director (Rashid), Crossroads Clinic, Women's College Hospital; Medical Director (Berger), Inner City Health Program, St. Michael's Hospital Toronto, Toronto, Ont.

\section{References}

1. Alexander C. Health care and refugees in Canada. CMAJ 2014; 186:614-5.

2. Stanbrook MB. Canada owes refugees adequate health coverage. CMAJ 2014;186:91

CMAJ 2014. DOI:10.1503/cmaj.114-0032

\section{Docs should set an example}

How much money have organizations like Canadian Doctors for Refugee Care raised for Canadian refugees who need medical care? Setting up a charity can be a huge undertaking, so how about physicians lobby larger medical organizations, like the Canadian Medical Association, to take a stand and do some real work? ${ }^{1}$

Respectfully, Canadian Doctors for Refugee Care likely has many members. Most doctors in Canada are not in want of more money. How many members would sign a public pledge refusing to charge refugee claimants any fee? How many members have put pressure on their own hospitals to treat refugee claimants free of charge?

I suspect that the general public sees only a bunch of rich doctors asking other people to put up more money. This isn't a great image. Lobbying the government is good, but I think what will get the public to join our cause is putting our money where our mouths are. Health advocacy demands that we as doctors set an example, which is a huge challenge to be sure, but one that is noble and worthwhile.

Doctors frequently admonish the public about bad eating habits and obesity. How much do we as a group publicly show that we incorporate healthy living in our lives? How many physicians are obese? How many smoke? How many never exercise? Doctors have advocated loudly for safe cellphone use in cars, yet many doctors use cellphones while driving. When will we demand higher standards for ourselves, before we demand it of others?

\section{James Chan MD}

The Ottawa Hospital, Ottawa, Ont.

\section{Reference}

1. Stanbrook MB. Canada owes refugees adequate health coverage. CMAJ 2014;186:91.

CMAJ 2014. DOI:10.1503/cmaj.114-0033

\section{CORRECTION \\ Inaccurate numbers in Salon article \\ A Salon article $^{1}$ published in the Apr. 15, 2014, issue of CMAJ indicates that "[a]lmost 150 schools in over 60 countries are training Canadian students." The figures should have appeared as 130 schools and 30 countries. $^{2}$ CMAJ apolo- gizes for any confusion this oversight may have caused. \\ References \\ 1. Barer ML, Evans RG, Hedden L. False hope for Canadians who study medicine abroad. CMAJ 2014;186:552. \\ 2. Returning to Canada. Ottawa (ON): Canadian Resident Matching Service. Available: www.carms.ca/en /returning-to-canada (accessed 2014 Apr. 2) \\ CMAJ 2014. DOI:10.1503/cmaj.114-0034}

